\title{
Effect of housing system and dietary biotin supplementation on 2- Egg quality traits and some blood constituents
}

\author{
Okasha, H.M.A*; El Garhy, O.H.M. and El-Gendi, G. M \\ Animal prod. dept., Faculty of Agriculture, Benha University \\ Corresponding author: Hamada.okasha@ fagr.bu.edu.eg
}

\begin{abstract}
The present study was aimed to investigate the effect of housing system and dietary biotin supplementation on productive and metabolic performance of Benha line chickens. A total number of 224 chickens 20 weeks old and mean of body weight $(1742 \pm 20.1)$, were equally divided into two groups in a factorial arrangement design ( $2 \times 4 \times 3)$. Pullets of the first group were housed in cages of laying battery (with artificial insemination) two birds were kept per cage of $48 \times 40 \mathrm{~cm}\left(960 \mathrm{~cm}^{2} /\right.$ bird). Pullets of the second group were kept on deep litter laying houses (with natural mating) in a density of $900 \mathrm{~cm}^{2} /$ bird. Chickens of each group were then subdivided into four sub groups each of 25 females and 3 males according to dietary biotin supplementation. Pullets of the $1^{\text {st }}$ sub group were fed on basal layer diet and considered as control group, the $2^{\text {nd }}, 3^{\text {rd }}$ and $4^{\text {th }}$ sub groups were fed on basal diet supplemented with biotin at a level of 100, 150 and $200 \mu \mathrm{g} / \mathrm{kg}$ diet, respectively. The results obtained showed that, pullets housed in cages improved significantly relative weights of egg shell and albumin, indexes of egg shape, albumin and yolk, hatchability percentage and chick weight at hatch, it also decreased early, mid and late embryonic mortality, plasma total proteins, aspartate aminotransferase, creatinine and plasma uric acid. However pullets housed on deep litter improved yolk index, Haugh unit, fertility percentage, plasma levels of albumin, globulin and alanine aminotransferase. Biotin supplementation to layer diets at a level of 150 $\mu \mathrm{g} / \mathrm{kg}$ diet increased relative weight of egg shell and albumin, yolk index, fertility and hatchability percentage and decreased early, mid and late embryonic mortality. Chick weight at hatch, egg shape index, relative weight of albumin and plasma level of albumin significantly increased by adding $100 \mu \mathrm{g}$ biotin to layers diets. It could be concluded that biotin supplementation at a level of 150 and $100 \mu \mathrm{g} / \mathrm{kg}$ in layer diet and reared in battery cages and on deep litter system, respectively seemed to be adequate to achieve the favorable results.
\end{abstract}

Key words: laying hens, housing system, biotin, Egg quality, blood.

\section{Introduction}

Laying-hen housing may have different schemes in modern production agriculture, including traditional cages, enriched cages, cage-free floorraised house or aviary, or free range system. Each housing scheme has come into practice for various reasons as the scale of production has increased from the family farm to commercial-scale operations. Each system offers benefits to the producer, the bird, the consumer, or a combination. Alternative housing systems for laying hens must be designed to balance the health and the welfare of the birds with consumer preferences, the needs of the industry, and the impact on environment. Housing systems for laying hens have considerable effects on performance and production traits such as egg weight, feed efficiency and daily feed consumption (Suto et al., 1997). Egg quality is important for consumer appeal, and the economic success of a producer depends on the total number of eggs sold. Egg quality has a genetic basis and its parameters vary between strains of hens (Silversides et al., 2007) and also influenced by the housing system under which the hens are kept (Vits et al., 2005). Blood biochemical analysis is very important among the research because it supports and interpret the results of the research (Ozbey and Esen. 2007 a). The study of the variation in blood picture and constituents in the fowls sets an important foundation to the study of growth and egg production. Moreover, it helps in explaining the reaction of developed strains of poultry to their environments.

Biotin (also known as vitamin $\mathrm{H}$ ), a water-soluble vitamin belonging to the B-complex group (Ploux, 2000), is necessary for normal embryonic development and hatchability (Whitehead et al., 1985). Its physiologically active form is linked to enzymes of great metabolic importance like biotin carboxylase and biotin decarboxylase and seems to be a key-enzyme in important processes like gluconeogenesis, fatty acids and protein synthesis, controlling scleroprotein production. Because of its functions, this vitamin contributes to such important processes as growth, skin regeneration, bone development and reproduction, increasing feed conversion in animals (McMahon, 2002). Therefore, the objective of this study was to evaluate the effect of housing system and dietary levels of biotin supplementation on egg quality traits and some blood constituents of Benha line chickens as a native breed of chickens in Egypt.

\section{Materials and Methods}

\section{Experimental birds and housing:}

A total number of 224( 200 hens and 24 cocks), Benha line chickens 20 weeks old and overall mean 
of body weight $(1742 \pm 20.1)$ were equally divided into two groups. Pullets of the first group were housed in cages of laying battery (with artificial insemination) two birds per cage of $48 \times 40 \times 40 \mathrm{~cm}$ $\left(960 \mathrm{~cm}^{2} / \mathrm{bird}\right)$. Pullets of the second group were kept on deep litter laying houses (with natural mating) in a density of $900 \mathrm{~cm}^{2} /$ bird. Chickens of each group were then subdivided into four sub groups each of 25 females and 3 males according to dietary biotin supplementation. Pullets of the $1^{\text {st }}$ sub group were fed on basal layer diet and considered as control group, the $2^{\text {nd }}, 3^{\text {rd }}$ and $4^{\text {th }}$ sub groups were fed on basal diet supplemented with biotin at a level of 100, 150 and $200 \mu \mathrm{g} / \mathrm{kg}$ diet, respectively. The basal layer diet (Table, 1) was formulated according to (NRC, 1994) with $15.68 \%$ crude protein and $2726 \mathrm{kcal} / \mathrm{kg}$. The experimental diets and fresh water were supplied ad libitum.

Table 1.Composition* and calculated nutritional value of starting, growing and basal layer diet.

\begin{tabular}{|c|c|c|c|}
\hline \multirow[b]{2}{*}{ Ingredients \% } & \multicolumn{3}{|c|}{ Ration } \\
\hline & $\begin{array}{c}\text { Starting } \\
0-8 \text { wks age }\end{array}$ & $\begin{array}{c}\text { Growing } \\
\text { 9-19 wks age }\end{array}$ & $\begin{array}{c}\text { Laying } \\
20 \text { wks after }\end{array}$ \\
\hline Yellow corn & 65.00 & 63.00 & 66.00 \\
\hline Soybean meal $44 \%$ & 30.45 & 15.50 & 21.30 \\
\hline Wheat bran & 0.65 & 17.78 & 2.94 \\
\hline Di-calcium phosphate & 1.80 & 1.25 & 1.50 \\
\hline Limestone & 1.40 & 1.80 & 7.60 \\
\hline Salt & 0.30 & 0.30 & 0.30 \\
\hline Vit \& Min. premix $* *$ & 0.30 & 0.30 & 0.30 \\
\hline DI-Methionine & 0.10 & 0.07 & 0.06 \\
\hline Total & 100.00 & 100.00 & 100.00 \\
\hline \multicolumn{4}{|l|}{ Calculated analysis: } \\
\hline Curd protein \% & 19.278 & 15.196 & 15.676 \\
\hline M.E. (k cal/kg) & 2868.665 & 2689.866 & 2726.418 \\
\hline Crude fiber \% & 3.723 & 4.472 & 3.329 \\
\hline Crude fat \% & 2.723 & 3.051 & 2.766 \\
\hline Calcium \% & 1.016 & 1.030 & 3.285 \\
\hline Avail. Phosphorus \% & 0.485 & 0.397 & 0.412 \\
\hline Lysin \% & 1.051 & 0.709 & 0.799 \\
\hline Methionine \% & 0.428 & 0.326 & 0.334 \\
\hline Cystin \% & 0.180 & 0.180 & 0.180 \\
\hline Meth. + Cys. \% & 0.737 & 0.571 & 0.588 \\
\hline
\end{tabular}

Parameters estimation and data collection:-

During two successive days out of each week, 20 eggs of each treatment were collected and individually subjected to the following measurements and estimation. Egg components (egg shell, albumen and yolk) in terms of the percentage of egg were determined, egg shape index (ESI) was calculated according to the following equation reported by Stadelman (1977), [ESI = (egg width/egg length) $\mathrm{x}$ 100]. Albumen index was calculated according to Romanoff and Romanoff, (1949) as follows: $\mathrm{AI}=$ [albumen height / (albumen diameter)/2) ×100]. Yolk index was calculated according to Wesley and Stadelman (1959). Haugh unit was calculated according to, Haugh (1937) as follows: $\mathbf{H U}=\mathbf{1 0 0} \mathbf{l o g}$ $\left(\mathbf{H}+\right.$ 7.37-1.7 EW $\left.^{\mathbf{0 . 3 7}}\right)$, Where: $\mathrm{H}=$ Albumen height $(\mathrm{mm})$. EW = Egg weight $(\mathrm{g})$. Data were then presented at sexual maturity, at the peak of egg production and at the end of the experimental period (lasted 180 days of egg production).
During egg production periods, eggs were collected and incubated monthly (6 batches). At hatching time, infertile eggs were examined to determined fertility percentage. Fertility percentage was calculated using the following equation: Fertility $(\%)=$ Number of fertile eggs / Number of setting eggs $\mathrm{x} 100$, hatchability percentage was calculated according to the following equation: Hatchability $(\%)=$ Number of hatched chicks / Number of fertile eggs x100, chick weight at hatch was calculated and Percentages of early, mid and late embryonic mortality were also calculated.

Blood samples were taken for chemical determination at sexual maturity, at the peak of egg production and at the end of the experimental period. Blood samples were withdrawn from four females randomly selected from each experimental treatment into the tube contain EDTA, Plasma was separated by using centrifugation for 20 minutes of $2500 \mathrm{rpm}$. Then all samples were transferred and stored in the deep freezer at approximately $-20 \mathrm{C}^{\mathrm{o}}$ until the time of 
the biochemical analysis. Plasma total protein, albumin and globulin, aspartate aminotransferase (AST) and alanine aminotransferase (ALT), creatinine and plasma uric acid were calorimetrically estimated using commercial kits purchased from (Spectrum Bio- Diagnostic Company, HannoverGermany).

\section{Statistical analysis}

Analysis of variance was carried out using SAS procedure guide (SAS, 2004). According to the following linear model 1:

$\mathbf{X}_{\mathrm{ijk}}=\boldsymbol{\mu}+\mathbf{H i}+\mathbf{B}_{\mathbf{j}}+\mathbf{P}_{\mathbf{k}}+\mathbf{e}_{\mathbf{i j k}}$

$\mathbf{X}_{\mathrm{ijk}}=$ the $\mathrm{k}^{\text {Th }}$ observation, $\boldsymbol{\mu}=$ the overall mean. $\mathbf{H}_{\mathbf{i}}=$ the effect of the housing system. (I, 1-2), $\mathbf{B}_{\mathbf{j}}=$ the effect of the biotin supplementation. $(\mathrm{J}, 1-4) \mathbf{P}_{\mathbf{k}}=$ the effect of the Experimental period. $(\mathrm{K}, 1-3)$ and $\mathbf{e}_{\mathbf{i j k}}=$ the experimental error.

Significant differences among groups means were tested using Duncan multiple range test (Duncan, 1955).

\section{Results and Discussion}

\section{Egg quality}

The results obtained for relative weights of egg component in terms of egg shell, albumin and yolk at age of sexual maturity, at the peak of egg production and at the end of the experimental period are shown in Table (2). During the different periods of the experiment, it could be noticed that relative weights of yolk was significantly $(\mathrm{p}<0.01)$ increased in egg produced from birds reared on deep litter $(30.12 \%)$ than those produced from birds reared in cages $(29.95 \%)$. While relative weight of egg shell and albumin were not significantly affected by housing system, it was clearly observed that egg produced from birds reared in cages showed the higher relative weights of egg shell and albumen $(12.86 \%$ and $59.37 \%$,respectively) than those produced from birds reared on deep litter $(12.80 \%$ and $59.34 \%$,respectively). The non-significant difference in egg shell percent due to housing system may be attributed to those hens received a balances diet which may be sufficient to cover their requirements, thus the genetic effect become dominant for controlling this trait rather than housing system (EIGendi, 1985).

Table 2. Least - square means and standard error $(\mathrm{LSM} \pm \mathrm{S} . \mathrm{E}) \quad$ for relative weights of egg shell, albumen and yolk as affected by the studied factors

\begin{tabular}{|c|c|c|c|c|}
\hline \multirow[t]{2}{*}{ Factors } & \multirow[b]{2}{*}{ Treatment } & \multicolumn{3}{|c|}{ Relative weights of egg component (\%) } \\
\hline & & Shell & Albumen & Yolk \\
\hline \multirow{2}{*}{ Housing system } & Cages & $12.86 \pm 0.27$ & $59.37 \pm 0.49$ & $29.95 \pm 0.28^{b}$ \\
\hline & Deep litter & $12.80 \pm 0.27$ & $59.34 \pm 0.49$ & $30.12 \pm 0.28^{\mathrm{a}}$ \\
\hline \multirow{4}{*}{$\begin{array}{l}\text { Biotin levels } \\
(\mu \mathrm{g} / \mathrm{kg})\end{array}$} & Control & $12.70 \pm 0.38$ & $58.94 \pm 0.70$ & $30.05 \pm 0.40^{\mathrm{ab}}$ \\
\hline & 100 & $12.93 \pm 0.38$ & $59.64 \pm 0.70$ & $29.80 \pm 0.40^{\mathrm{b}}$ \\
\hline & 150 & $12.96 \pm 0.38$ & $59.34 \pm 0.70$ & $29.83 \pm 0.40^{\mathrm{b}}$ \\
\hline & 200 & $12.72 \pm 0.38$ & $59.39 \pm 0.70$ & $30.47 \pm 0.40^{\mathrm{a}}$ \\
\hline \multirow{3}{*}{$\begin{array}{l}\text { Experimental } \\
\text { period }\end{array}$} & Sexual maturity & $13.43 \pm 0.43^{\mathrm{a}}$ & $58.49 \pm 0.60^{\mathrm{a}}$ & $28.32 \pm 0.34^{\mathrm{c}}$ \\
\hline & Peak & $12.69 \pm 0.43^{\mathrm{ab}}$ & $60.07 \pm 0.60^{\mathrm{a}}$ & $30.23 \pm 0.34^{\mathrm{b}}$ \\
\hline & End & $12.37 \pm 0.43^{b}$ & $59.50 \pm 0.60^{\mathrm{b}}$ & $31.55 \pm 0.34^{\mathrm{a}}$ \\
\hline
\end{tabular}

(a, b, c, d ) means within each factor with different superscripts are significantly different.

The results obtained agreed with those reported by Singh et al., (2009) who found that eggs produced in cages had significantly lower yolk weights than those laid on floor. However, El-Anwer et al., (2009) and Hassan (2001) who, stated that there were no significant differences in egg shell percent and albumin percent under either housing system battery cages and/or floor deep litter.

Pullets fed diet supplemented with biotin at a level of $150 \mu \mathrm{g} / \mathrm{kg}$ diet showed the higher value of relative weight of egg shell $(12.96 \%)$, while pullets fed diet supplemented with biotin at a level of $100 \mu \mathrm{g}$ $/ \mathrm{kg}$ diet showed the higher value of relative weight of albumin (59.64\%). However increasing biotin level to $200 \mu \mathrm{g} / \mathrm{kg}$ diet significantly increased relative weight of yolk (30.47\%). Bennett (1992), Narushin, (1997), Moyle et al., (2008) and Butcher and Miles (2011) stated that there is a little information regarding biotin supplementation on egg quality characters.
Shell weight percentage increased significantly at sexual maturity then decreased toward the end of the experimental period. However, the relative weights of albumen and yolk significantly increased at the peak of egg production and at the end of the experimental period, respectively. A number of studies had shown that egg shell quality decreases as birds grow older (Nys, 1985 and Roberts and Ball, 2004).

The results obtained in Table (3) showed that eggs produced from pullets reared in cages had the higher egg shape index $(80.01 \mathrm{~mm})$, albumen index $(15.79 \mathrm{~mm})$ and yolk index $(53.13 \mathrm{~mm})$ than those laid by pullets reared on deep litter $(75.22,14.88$ and $51.89 \mathrm{~mm}$, respectively). The results obtained agree with those reported by El-Anwer et al., (2009) and Singh et al., (2009) they found that indexes of egg shape, albumen and yolk from cages eggs were significantly $(\mathrm{P} \leq 0.05)$ higher in pullets reared in cage than those laid on floor. 
Pullets fed diet supplemented with biotin at a level of $100 \mu \mathrm{g}$ biotin / $\mathrm{kg}$ diet produced the highest average of egg shape index $(79.21 \mathrm{~mm})$, while those fed diet supplemented $150 \mu \mathrm{g}$ biotin / $\mathrm{kg}$ diet showed the highest averages of egg albumen index $(15.56 \mathrm{~mm})$ and yolk index $(53.27 \mathrm{~mm})$. Albumen and yolk index increased gradually reaching its maximum values at the end of the experimental period.

Data listed in Table (3) revealed that pullets reared on deep litter laid eggs with higher Haugh unit value (87.04) than those laid by pullets reared in cages (86.81). These results disagree with those reported by Ozbey and Esen (2007 b) who observed a significant difference in eggs Haugh unit values in favor of cage system. Haugh unit value increased with increasing biotin level supplementation, eggs laid from pullets fed diet supplemented with biotin at a level of 200 and $150 \mu \mathrm{g} / \mathrm{kg}$ diet showed the higher averages of haugh unit value (87.11and 87.08, respectively). These results agree with those reported by Abdel-Mageed and Shabaan (2012) who found that biotin addition to layers diets gave the best improvement in Haugh unit.

Haugh units increased gradually with increasing of birds age reaching its maximum values at the end of experimental period.

Table 3. Least - square means and standard error $(\mathrm{LSM} \pm$ S.E) for egg shape, albumen, yolk indexes as affected by the studied factors

\begin{tabular}{lccccc}
\hline \multirow{2}{*}{ Factors } & Treatment & \multicolumn{3}{c}{ Index (mm) of } & \multirow{2}{*}{ Haugh unit } \\
\cline { 2 - 5 } Housing system & Cages & $80.01 \pm 1.71$ & $15.79 \pm 0.46$ & $53.13 \pm 1.34$ & $86.81 \pm 0.48$ \\
\cline { 2 - 5 } & Deep litter & $75.22 \pm 1.71$ & $14.88 \pm 0.46$ & $51.89 \pm 1.34$ & $87.04 \pm 0.48$ \\
\hline \multirow{3}{*}{$\begin{array}{l}\text { Biotin levels } \\
(\mu \mathrm{g} / \mathrm{kg})\end{array}$} & $\mathbf{C o n t r o l}$ & $75.86 \pm 2.43$ & $15.13 \pm 0.65$ & $50.60 \pm 1.90$ & $86.56 \pm 0.69$ \\
\cline { 2 - 5 } & $\mathbf{1 0 0}$ & $79.21 \pm 2.43$ & $15.40 \pm 0.65$ & $53.00 \pm 1.90$ & $86.95 \pm 0.69$ \\
\cline { 2 - 5 } & $\mathbf{1 5 0}$ & $77.15 \pm 2.43$ & $15.56 \pm 0.65$ & $53.27 \pm 1.90$ & $87.08 \pm 0.69$ \\
\hline \multirow{2}{*}{$\begin{array}{l}\text { Experimental } \\
\text { period }\end{array}$} & $\mathbf{2 0 0}$ & $78.25 \pm 2.43$ & $15.25 \pm 0.65$ & $53.18 \pm 1.90$ & $87.11 \pm 0.69$ \\
\cline { 2 - 5 } & Sexual maturity & $75.54 \pm 2.10$ & $14.68 \pm 0.56$ & $50.29 \pm 1.65$ & $85.23 \pm 0.59^{\mathrm{b}}$ \\
\hline & Peak & $79.54 \pm 2.10$ & $15.61 \pm 0.56$ & $51.54 \pm 1.65$ & $87.63 \pm 0.59^{\mathrm{a}}$ \\
\hline & End & $77.78 \pm 2.10$ & $15.73 \pm 0.56$ & $53.11 \pm 1.65$ & $87.91 \pm 0.59^{\mathrm{a}}$ \\
\hline
\end{tabular}

(a, b ) means within each factor with different superscripts are significantly different.

\section{Fertility and hatchability:-}

Data presented in Table (4) revealed that, no significant variations was found in fertility due to the effect of housing system, it was clearly observed that eggs produced from birds reared on floor deep litter (natural mating) showed a higher fertility percentage $(82.70 \%)$ than those produced from birds reared in cages (artificially inseminated) it was mounted (81.94\%), this result may be attributed to the type of mating rather than the effect of housing system (Balcazar, 2014). Eggs produced from birds reared in cages had significantly higher average of hatchability percentage $(88.10 \%)$ than those produced from birds reared on floor $(80.64 \%)$, this result may be attributed to the differences in the internal and external characteristics of incubated eggs collected from pullets reared under these two different housing systems (El-Gendi, 1985).

Fertility and hatchability percentages of eggs produced from birds of the experimental groups increased significantly by increasing biotin level supplementation reaching its maximum values (86.87 and $89.29 \%$, respectively) for birds fed diets supplemented with biotin at a level of $150 \mu \mathrm{g} / \mathrm{kg}$ diet, then it decreased significantly at the higher level of biotin $(200 \mu \mathrm{g} / \mathrm{kg}$ diet) reaching to (84.51 and $82.34 \%$, respectively). These results agree with those reported by Chen et al., (1994), Nofal and Salem (2000) McMahon, (2002) and ROBEL (2002).

Table 4. Least -square means and standard error for fertility and hatchability as affected by the studied factor Factors Trait Fertility (\%) Hatchability (\%)

Treatment

\begin{tabular}{lccc}
\hline \multirow{3}{*}{ Housing system } & Cages & $81.94 \pm 1.63$ & $88.10 \pm 1.55^{\mathrm{a}}$ \\
\cline { 2 - 4 } $\begin{array}{l}\text { Biotin levels } \\
\boldsymbol{\mu} \mathbf{\mu g} / \mathbf{k g})\end{array}$ & Deep litter & $82.70 \pm 1.63$ & $80.64 \pm 1.55^{\mathrm{b}}$ \\
\cline { 2 - 4 } & Control & $74.50 \pm 2.30$ & $81.20 \pm 2.19^{\mathrm{b}}$ \\
\cline { 2 - 4 } & $\mathbf{1 0 0}$ & $83.35 \pm 2.30$ & $86.61 \pm 2.19^{\mathrm{ab}}$ \\
\cline { 2 - 4 } $\begin{array}{lccc}\text { Experimental } \\
\text { period }\end{array}$ & $\mathbf{1 5 0}$ & $86.87 \pm 2.30$ & $89.29 \pm 2.19^{\mathrm{a}}$ \\
\cline { 2 - 4 } & $\mathbf{2 0 0}$ & $84.51 \pm 2.30$ & $82.34 \pm 2.19^{\mathrm{b}}$ \\
\cline { 2 - 4 } & Sexual maturity & $79.04 \pm 1.99$ & $91.61 \pm 1.86^{\mathrm{a}}$ \\
\cline { 2 - 4 } & Peak & $84.31 \pm 1.99$ & $84.19 \pm 1.86^{\mathrm{b}}$
\end{tabular}

(a, b) means within each factor with different superscripts are significantly different. 
Embryonic mortality:-

Data obtained in Table (5) revealed that incubated egg from pullets reared in cages significantly decreased $(\mathrm{p}<0.05)$ percentage of early $(3.19 \%)$, mid $(1.76 \%)$ and late $(2.67 \%)$ embryonic mortality, than those reared on floor $(6.90 \%, 4.03 \%$ and $3.72 \%$, respectively). Pullets fed diet supplemented with biotin at a level of $150 \mu \mathrm{g} / \mathrm{kg}$ diet showed significantly $(\mathrm{P}<0.05)$ the lowest percentages of early $(2.93 \%)$, mid $(2.20 \%)$ and late $(2.79 \%)$ embryonic mortality compared with different levels of biotin applied and control group. The results obtained agree with those reported by AbdelMageed and Shabaan (2012) who found that increasing biotin level from 162.5 to $325.5 \mu \mathrm{g} / \mathrm{kg}$ gave a significant decrease in the percentages of early and late embryonic mortality.

\section{Chick weight at hatch:}

Data presented in Table, (6) revealed that significant $(\mathrm{P}<0.05)$ variations due to the effect of housing system on chick weight at hatch, it was clearly observed that incubated eggs produced from pullets reared in cages had a higher chick weight at hatch $(36.17 \mathrm{~g})$ than those reared on deep litter $(33.32 \mathrm{~g})$. This result is quite true and logic since the increasing in egg weight may be attributed to the increasing chick weight at hatch (Van de Ven et al., 2009). Incubated eggs produced from pullets fed diet supplemented with biotin at a level of $100 \mu \mathrm{g} / \mathrm{kg}$ had significantly $(p<0.05)$ the higher chick weight at hatch $(36.03 \mathrm{~g})$, followed by those fed diet supplemented with $150 \mu \mathrm{g} / \mathrm{kg}(35.33 \mathrm{~g})$. The increase chick weight at hatch observed in this study may be due to the increase in egg weight. In this respect, Abiola (1999) found a close correlation between egg weight and hatching weight in domestic birds. Abdel-Mageed and Shabaan (2012) found that supplemented biotin at a level of $100 \mu \mathrm{g} / \mathrm{kg}$ to layer diet gave significant increase in chick weight at hatch. Chick weight at hatch increased significantly by advancing age reaching its maximum value at the end of the experimental period.

Table 5. Least - square means and standard error (LSM \pm S.E) for early, mid and late embryonic mortality as affected by the studied factors

\begin{tabular}{lcccc}
\hline Factors & \multicolumn{1}{c}{ Trait } & \multicolumn{2}{c}{ Embryonic mortality (\%) } \\
\cline { 2 - 4 } & Treatment & Early & Mid & Late \\
\hline \multirow{3}{*}{ Housing system } & Cages & $3.19 \pm 0.22^{\mathrm{b}}$ & $1.76 \pm 0.14^{\mathrm{b}}$ & $2.67 \pm 0.15^{\mathrm{b}}$ \\
\cline { 2 - 4 } $\begin{array}{l}\text { Biotin levels } \\
(\boldsymbol{\mu g} / \mathbf{k g})\end{array}$ & Deep litter & $6.90 \pm 0.22^{\mathrm{a}}$ & $4.03 \pm 0.14^{\mathrm{a}}$ & $3.72 \pm 0.15^{\mathrm{a}}$ \\
\cline { 2 - 4 } & Control & $6.58 \pm 0.31^{\mathrm{a}}$ & $3.83 \pm 0.21^{\mathrm{a}}$ & $3.64 \pm .22^{\mathrm{a}}$ \\
\cline { 2 - 4 } & $\mathbf{1 0 0}$ & $5.31 \pm 0.31^{\mathrm{b}}$ & $2.52 \pm 0.21^{\mathrm{bc}}$ & $3.25 \pm .22^{\mathrm{ab}}$ \\
\cline { 2 - 4 } & $\mathbf{1 5 0}$ & $2.93 \pm 0.31^{\mathrm{c}}$ & $2.20 \pm 0.21^{\mathrm{c}}$ & $2.79 \pm .22^{\mathrm{b}}$ \\
\hline $\begin{array}{l}\text { Experimental } \\
\text { period }\end{array}$ & $\mathbf{2 0 0}$ & $5.37 \pm 0.31^{\mathrm{b}}$ & $3.02 \pm 0.21^{\mathrm{b}}$ & $3.12 \pm .22^{\mathrm{ab}}$ \\
\cline { 2 - 4 } & Sexual maturity & $8.35 \pm 0.27^{\mathrm{a}}$ & $5.12 \pm 0.18^{\mathrm{a}}$ & $6.60 \pm 0.19^{\mathrm{a}}$ \\
\hline & Peak & $2.15 \pm 0.27^{\mathrm{c}}$ & $0.57 \pm 0.18^{\mathrm{c}}$ & $1.01 \pm 0.19^{\mathrm{c}}$ \\
\hline
\end{tabular}

$(a, b, c)$ means within each factor with different superscripts are significantly different.

Table 6. Least - square means and standard error $(\mathrm{LSM} \pm$ S.E) for chick weight at hatch as affected by the studied factors

\begin{tabular}{|c|c|c|}
\hline Factors & Treatment & Chick Weight at hatch (g) \\
\hline \multirow[b]{2}{*}{ Housing system } & Cages & $36.17 \pm 0.32^{\mathrm{a}}$ \\
\hline & Deep litter & $33.32 \pm 0.32^{\mathrm{b}}$ \\
\hline \multirow{4}{*}{$\begin{array}{l}\text { Biotin levels } \\
(\mu \mathrm{g} / \mathrm{kg})\end{array}$} & Control & $33.16 \pm 0.46^{\mathrm{c}}$ \\
\hline & 100 & $36.03 \pm 0.46^{\mathrm{a}}$ \\
\hline & 150 & $35.33 \pm 0.46^{\mathrm{ab}}$ \\
\hline & 200 & $34.46 \pm 0.46^{\mathrm{b}}$ \\
\hline \multirow{3}{*}{ Experimental period } & Sexual maturity & $33.25 \pm 0.40^{\mathrm{b}}$ \\
\hline & Peak & $35.00 \pm 0.40^{\mathrm{a}}$ \\
\hline & End & $36.01 \pm 0.40^{\mathrm{a}}$ \\
\hline
\end{tabular}

$(a, b)$ means within each factor with different superscripts are significantly different.

\section{Blood constituents:-}

The obtained data presented in Table (7) showed that pullets kept on deep litter laying house had significantly the higher level of plasma total proteins $(6.05 \mathrm{~g} / \mathrm{dL})$ than caged ones $(4.52 \mathrm{~g} / \mathrm{dl})$, while, pullets kept in cages had significantly the higher levels of plasma albumen and globulin (3.15 and $3.19 \mathrm{~g} / \mathrm{dL}$, respectively). These results agree with those reported by El- Anwer et al., (2009) who 
found that there was a significant increase in plasma total proteins at $36 \mathrm{wks}$ in floor hens.

Plasma protein fractions significantly affected by dietary biotin level, pullets fed diet supplemented with biotin at a level of 100 and $150 \mu \mathrm{g} / \mathrm{kg}$ showed significantly the higher plasma albumin concentration (3.43 and $3.00 \mathrm{~g} / \mathrm{dL}$ ). However control group significantly increased in plasma total protein and globulin compared with different biotin level supplementations these results disagree with those reported by Al-Salih et al., (2012) who found that the treated rabbits with a dose of $200 \mu \mathrm{g}$ biotin / $\mathrm{kg}$ evoked a significant increase in the concentrations of each total protein, albumin, and globulin.

Table 7. Least - square means and standard error (LSM \pm S.E) for plasma total proteins, albumin and globulin as affected by the studied factors

\begin{tabular}{|c|c|c|c|c|}
\hline Factors & Treatment & $\begin{array}{c}\text { Total proteins } \\
\text { (g/dl) }\end{array}$ & $\begin{array}{c}\text { Albumin } \\
(\mathrm{g} / \mathrm{dl})\end{array}$ & $\begin{array}{c}\text { Globulin } \\
\text { (g/dl) }\end{array}$ \\
\hline \multirow{2}{*}{ Housing system } & Cages & $4.52 \pm 0.14^{\mathrm{b}}$ & $3.15 \pm 0.09^{\mathrm{a}}$ & $3.19 \pm 0.15^{\mathrm{a}}$ \\
\hline & Deep litter & $6.05 \pm 0.14^{\mathrm{a}}$ & $2.86 \pm 0.09^{b}$ & $1.36 \pm 0.15^{\mathrm{b}}$ \\
\hline \multirow{4}{*}{$\begin{array}{l}\text { Biotin levels } \\
(\mu \mathrm{g} / \mathrm{kg})\end{array}$} & Control & $5.55 \pm 0.19^{\mathrm{a}}$ & $2.95 \pm 0.12^{\mathrm{b}}$ & $2.60 \pm 0.22^{\mathrm{a}}$ \\
\hline & 100 & $5.47 \pm 0.19^{\mathrm{ab}}$ & $3.43 \pm 0.12^{\mathrm{a}}$ & $2.03 \pm 0.22^{\mathrm{a}}$ \\
\hline & 150 & $5.26 \pm 0.19^{\mathrm{ab}}$ & $3.00 \pm 0.12^{\mathrm{b}}$ & $2.25 \pm 0.22^{\mathrm{a}}$ \\
\hline & 200 & $4.88 \pm 0.19^{\mathrm{b}}$ & $2.64 \pm 0.12^{b}$ & $2.23 \pm 0.22^{\mathrm{a}}$ \\
\hline \multirow{3}{*}{$\begin{array}{l}\text { Experimental } \\
\text { period }\end{array}$} & Sexual maturity & $5.41 \pm 0.17$ & $3.03 \pm 0.11$ & $2.37 \pm 0.19$ \\
\hline & Peak & $5.09 \pm 0.17$ & $2.85 \pm 0.11$ & $2.24 \pm 0.19$ \\
\hline & End & $5.37 \pm 0.17$ & $3.14 \pm 0.11$ & $2.22 \pm 0.19$ \\
\hline
\end{tabular}

$(a, b)$ means within each factor with different superscripts are significantly different.

Data presented in Table (8) showed that the higher levels of plasma AST and ALT transaminases (133.01 and 48.16 U/L) were found in pullets housed in deep floor litter and battery cages, respectively.

Pullets fed diet supplemented with biotin at a level of $200 \mu \mathrm{g} / \mathrm{kg}$ had significantly the highest averaged of plasma AST (159.79) and ALT transaminases $(67.30 \mathrm{U} / \mathrm{L})$. These results agree with those reported by Grier et al., (1990) and Mutluay et al., (2008) they found that there were significantly affected on serum AST and ALT Levels $(\mathrm{p}<0.05)$ due to biotin supplementation to layer diet. Plasma AST significantly increased with advanced age reaching its maximum value $(148.21 \mathrm{U} / \mathrm{L})$ at the end of the experimental period.

Data presented in Table (9) revealed highly significant $(\mathrm{P}<0.05)$ variation in plasma uric acid and creatinine due to housing system applied, the higher averages of plasma creatinine $(1.22 \mathrm{mg} / \mathrm{dL})$ and uric acid $(7.60 \mathrm{mg} / \mathrm{dL})$ were found in pullets kept on deep litter laying houses.
Regarding the effect of biotin level, it is clearly observed that pullets fed diet supplemented with biotin at a level of $150 \mu \mathrm{g} / \mathrm{kg}$ showed significantly the highest averages of plasma creatinine and uric acid level (1.26 and $8.16 \mathrm{mg} / \mathrm{dL}$, respectively). However, the lower plasma creatinine and uric acid levels (1.11 and $5.87 \mathrm{mg} / \mathrm{dL}$, respectively) showed in pullets fed diet supplementation with biotin at a level of $200 \mu \mathrm{g} / \mathrm{kg}$. These results agree with those reported by Al-Salih et al., (2012) they found that treated rabbits with a dose of $200 \mu \mathrm{g}$ biotin $/ \mathrm{kg}$ evoked a significant decrease in uric acid concentration in their blood serum.

Plasma creatinine and uric acid showed the lowest averages 0.88 and $6.26 \mathrm{mg} / \mathrm{dL}$ at the end of the experimental period and at the peak of egg production, respectively. (Table 9)

It could be concluded that biotin supplementation at a level of 150 and $100 \mu \mathrm{g} / \mathrm{kg}$ in layer diet and reared in both battery cages and on deep litter system, respectively seemed to be adequate to achieve the favorable results.

Table 8. Least - square means and standard error (LSM \pm S.E) for plasma Aspartate aminotransferase (AST) and Alanine Aminotransferase (ALT) as affected by the studied factors

\begin{tabular}{|c|c|c|c|}
\hline Factors & Treatment & $\operatorname{AST}(\mathbf{U} / L)$ & ALT (U/L) \\
\hline \multirow{2}{*}{ Housing system } & Cages & $120.21 \pm 8.97^{\mathrm{a}}$ & $48.16 \pm 7.17^{\mathrm{a}}$ \\
\hline & Deep litter & $133.01 \pm 8.97^{\mathrm{a}}$ & $45.95 \pm 7.17^{\mathrm{a}}$ \\
\hline \multirow{4}{*}{$\begin{array}{l}\text { Biotin levels } \\
(\mu \mathrm{g} / \mathrm{kg})\end{array}$} & Control & $115.00 \pm 12.68^{\mathrm{b}}$ & $44.42 \pm 10.15^{\mathrm{ab}}$ \\
\hline & 100 & $74.73 \pm 12.68^{\mathrm{c}}$ & $28.02 \pm 10.15^{\mathrm{b}}$ \\
\hline & 150 & $156.92 \pm 12.68^{\mathrm{a}}$ & $48.47 \pm 10.15^{\mathrm{ab}}$ \\
\hline & 200 & $159.79 \pm 12.68^{\mathrm{a}}$ & $67.30 \pm 10.15^{\mathrm{a}}$ \\
\hline \multirow{3}{*}{ Experimental period } & Sexual maturity & $111.90 \pm 10.98^{\mathrm{b}}$ & $47.77 \pm 8.79^{a}$ \\
\hline & Peak & $119.72 \pm 10.98^{\mathrm{ab}}$ & $41.57 \pm 8.79^{\mathrm{a}}$ \\
\hline & End & $148.21 \pm 10.98^{\mathrm{a}}$ & $51.82 \pm 8.79^{\mathrm{a}}$ \\
\hline
\end{tabular}

(a, b) means within each factor with different superscripts are significantly different. 
Table 9.Least -square means and standard error $(\mathrm{LSM} \pm$ S.E) for plasma creatinine and uric acid as affected by the studied factors

\begin{tabular}{|c|c|c|c|}
\hline Factors & Treatment & Creatinine (mg/dL) & Uric Acid (mg/dL) \\
\hline \multirow{2}{*}{ Housing system } & Battery & $1.13 \pm 0.13$ & $6.38 \pm 0.44^{\mathrm{b}}$ \\
\hline & Floor & $1.22 \pm 0.13$ & $7.60 \pm 0.44^{\mathrm{a}}$ \\
\hline \multirow{4}{*}{$\begin{array}{l}\text { Biotin levels } \\
(\mu \mathrm{g} / \mathrm{kg})\end{array}$} & Control & $1.13 \pm 0.19^{\mathrm{a}}$ & $6.98 \pm 0.63^{\mathrm{ab}}$ \\
\hline & 100 & $1.21 \pm 0.19^{\mathrm{a}}$ & $6.94 \pm 0.63^{\mathrm{ab}}$ \\
\hline & 150 & $1.26 \pm 0.19^{\mathrm{a}}$ & $8.16 \pm 0.63^{\mathrm{a}}$ \\
\hline & 200 & $1.11 \pm 0.19^{\mathrm{a}}$ & $5.87 \pm 0.63^{b}$ \\
\hline \multirow{3}{*}{ Experimental period } & Sexual maturity & $1.41 \pm 0.16^{\mathrm{a}}$ & $7.57 \pm 0.54^{\mathrm{a}}$ \\
\hline & Peak & $1.23 \pm 0.16^{\mathrm{ab}}$ & $6.26 \pm 0.54^{\mathrm{a}}$ \\
\hline & End & $0.88 \pm 0.16^{\mathrm{b}}$ & $7.14 \pm 0.54^{\mathrm{a}}$ \\
\hline
\end{tabular}

(a, b) means within each factor with different superscripts are significantly different.

\section{Reference}

Abdel-Mageed, M. A. A., \& Shabaan, S. A. M. (2012). Effect of supplemental biotin on the performance of aged fayoumi hens and progeny performance. Egypt. Poult. Sci. 32: 895-908.

Abiola, S. S., (1999). Effects of turning frequency of hen's egg in electric table-type incubator on weight losses, hatchability and mortality. Nig. Agr. J., 30: 77-82.

Al-Salih, N. A. W.; Jankeer M. H. and Al-Kattan M.M. (2012):: The Effect of Biotin (B7) on the Level of Some Non-enzymatic Antioxidants and Lipid Peroxidation in Blood Serums and Livers of Local Male Rabbits Exposed to Oxidative Stress by Hydrogen Peroxide. Damascus University Journal for Educational Sciences., 2: 29- 2013

Balcazar, P. E. E. (2014). The effects of limestone particle size on bone health and performance of pullets and hens in conventional cage and alternative housing systems (Doctoral dissertation, The University of NebraskaLincoln).

Bennett, C. D., (1992). The influence of shell thickness on hatchability in commercial broiler flocks. J. Appl. Poult. Res., 1: 61-65.

Butcher, G. and R. Miles, (2011). Egg specific gravity designing a monitoring program. IFAS Extension. University of Florida VM72.

Chen, F., S. L. Noll, and P. E. Waibel. 1994. Dietary biotin and turkey breeder performance. Poult. Sci. 73:682-686.

Duncan, D.B. (1955). Multiple range and multiple F tests. Biometrics.11: 1-42.

El-Anwer M. M. A., Salem Amina, M., AbouEitta, A., and Al-Kotait, H. A. (2009). A comparative study between two local strains under cage and floor housing systems. Egypt Poultry Science, 29, 439-464.

El-Gendi, G. M., (1985). Some factors affecting productive efficiency in chicken under subtropical conditions. M.Sc. Thesis, Fac. of
Agric., Moshtohor, Zagazig Univ. Benha branch, Egypt.

Grier, R. E., Heard, G. S., Watkins, P., and Wolf, B. (1990). Low biotinidase activities in the sera of patients with impaired liver function: evidence that the liver is the source of serum biotinidase. Clinica chimica acta, 186(3), 397-400.

Hassan, A.H.A. (2001). Egg quality traits as affected by strain, housing system and time of egg collection. J. Prod. \& Dev., 6:167-179.

Haugh, R. R., (1937). The Haugh unit for measuring egg quality. U.S. Egg Poultry Magazine, 43: 552553 and 572-573.

McMahon, R. J., (2002). Biotin in metabolism and molecular biology. Annu. Rev. Nutr., 22: 221 239.

Moyle, J., D. Yoho and K. Bramwell, (2008). Measuring hatching egg shell quality. University of Arkansas. Avian Advice., 10: 4.

Mutluay Arslan a, Sebahattin Vurucu b, Necati Balamtekin a, Bulent Unay b, Ridvan Akin b, Ismail Kurt c, Okan Ozcan a.(2008). The effects of biotin supplementation on serum and liver tissue biotinidase enzyme activity and alopecia in rats which were administrated to valproic acid, Elsevier B.V. doi:10.1016/j.braindev.2008.07.008, Brain \& Development 31 (2009) 405-410

Narushin, V., (1997). Non-destructive measurements of egg parameters quality characteristics. World's Poult. Sci., J., 57: 141153.

Nofal, M. E.; Salem, A. A. (2000).Effects of age hens and oviposition intervals in Mamourah a local chickens breed and their effects on hatching traits and chicks weights. Egypt. Sci. Mansoura Univ., 24(9): 4551- 4563.

NRC (1994). Nutrient requirements of Poultry National Research Council. ${ }^{\mathrm{N}}$ reviseded .Nat. Aced Press, Washington, D.C. USA.

Nys, Y. (1985). Relationships between age, shell quality and individual rate and duration of shell formation in domestic hens. British Poultry Science, 27:253-259 
Ozbey, O. and Esen, F. (2007 a). The effects of breeding systems and stocking density on some blood parameters of Rock partridges (Alectoris graeca). Poult. Sci., 86:420-422.

Ozbey, O. and Esen, F. (2007 b). The effects of different breeding systems on egg productivity and egg quality characteristics of Rock Partridges. Poult. Sci., 86:782-785.

Robel, E. J. (2002). Assessment of dietary and egg injected d-biotin, pyridoxine and folic acid on turkey hatchability: folic acid and poults weight. World's Poultry Science Journal, 58(3), 305-315.

Roberts, JR and Ball, W.2004. Egg quality guidelines for the Australian egg industry. Australian Egg Corporation Limited Publication 03/19, 32 pp.

Romanoff, A. I, and A. J. Romanoff, (1949). The avian egg. John Wiley and Sons, Inc. New York.

SAS (2004). SAS procedure guide version 6. 12th Ed. SAS institute Ine., cary, NC, USA.

Silversides, F.G.; Shaver, Mc. Q.D. and Song, Y. (2007). Pure line laying chickens at the Agassiz Research Center. Anim. Gen. Res. Inform., 40: 79-85.

Singh, R.; Cheng, K.M. and Silversides, F.G. (2009). Production performance and egg quality of four strains of laying hens kept in conventional cages and floor pens. Poult. Sci. 88:256-264
Stadelman, W. J. 1977. Quality identification of shell eggs in egg science and technology. 2nd ed. W. J. Stadelman and D. J. Cotterill, ed. AVI Publishing Company Inc., Westport, CT.

Suto, Z.; Horn, P. and Ujvari, J. (1997). The effect of different housing systems on production and egg quality traits of Brown and Leghorn type layers. Acta. Agaria. Kaosvariensis., 1:29-35.

Van de Ven, L. J. F., Van Wagenberg, A. V., Groot Koerkamp, P. W. G., Kemp, B., \& Van den Brand, H. (2009). Effects of a combined hatching and brooding system on hatchability, chick weight, and mortality in broilers. Poultry science, 88(11), 2273-2279.

Vits, A.; Weizenburger, D.; Hamann, H. and Distl, O. (2005). Influence of different small group systems on production traits, egg quality and bone breaking strength of laying hens. First communication: Production traits and egg quality. Zuchtungskunde., 77:303-323.

Wesley, R. L. and W. J. Stadelman, (1959). Measurement of interior egg quality. Poult. Sci., 38: 479-481.

Whitehead, C. C., R. A. Pearson, and K. M. Herron. 1985. Biotin requirements of broiler breeders fed diets of different protein content and effect of insufficient biotin on the viability of progeny. Br. Poult. Sci. 26:73-82 